\title{
What can the abundance of Grey Parrots on Príncipe Island tell us about large parrot conservation?
}

\section{Review Article \\ Cite this article: Valle S, Collar NJ, Melo M, and Marsden SJ (2020) What can the abundance of Grey Parrots on Príncipe Island tell us about large parrot conservation? Journal of Tropical Ecology 36, 293-297. https://doi.org/10.1017/ S0266467421000031}

Received: 24 February 2020

Revised: 5 August 2020

Accepted: 22 February 2021

\section{Keywords:}

Cavity nesting; ecology; nest competition; Psittacidae; wildlife trade

Author for correspondence:

*Simon Valle, Email: s.valle@bangor.ac.uk

\author{
Simon Valle ${ }^{1,2, \star}$, Nigel J. Collar ${ }^{3}$, Martim Melo ${ }^{4,5,6}$ and Stuart J. Marsden ${ }^{1}$
}

${ }^{1}$ School of Science \& the Environment, Manchester Metropolitan University, Chester Street, Manchester M1 5GD, UK; ${ }^{2}$ Current address: School of Natural Sciences, Bangor University, Bangor LL57 2UW, UK; ${ }^{3}$ BirdLife International, Pembroke Street, Cambridge CB2 3QZ, UK; ${ }^{4}$ Natural History and Science Museum, University of Porto, Praça Gomes Teixeira, 4099-002 Porto, Portugal; ${ }^{5} \mathrm{CIBIO}$ Research Centre in Biodiversity and Genetic Resources, InBIO Associated Laboratory, Campus Agrário de Vairão, 4485-661 Vairão, Portugal and ${ }^{6}$ FitzPatrick Institute, DST-NRF Centre of Excellence, University of Cape Town, Rondebosch 7701, Cape Town, South Africa (c) The Author(s), 2021. Published by Cambridge University Press. This is an Open Access article, distributed under the terms of the Creative Commons Attribution licence (http:// creativecommons.org/licenses/by/4.0/), which permits unrestricted re-use, distribution, and reproduction in any medium, provided the original work is properly cited.

\section{CAMBRIDGE} UNIVERSITY PRESS

\begin{abstract}
While populations of the Endangered Grey Parrot Psittacus erithacus have collapsed across its range, the species remains remarkably abundant on the island of Príncipe, Gulf of Guinea. We examine how aspects of its ecology interplay with local environmental conditions, to inform conservation strategies for this species and other large parrots. On Príncipe, parrots breed in large trees of common species, with nest densities $\left(42 \pm 34 \mathrm{~km}^{-2}\right)$ greatly exceeding those for any comparably sized parrot. Productivity is high (1.9 chicks per cavity), probably reflecting the absence of nest competitors and predators. Food sources are abundant and much of the island is inaccessible to trappers, so many nests are successful each year. Historically harvest has involved taking only chicks from trees in a few traditional patches. These conditions have combined to allow Grey Parrots to thrive on Príncipe, while elsewhere nest trees are timber targets, nest competition and nest predation are likely to be more intense, trapping is indiscriminate, and few areas remain unexploited by trappers. Preservation of large trees as breeding refugia, and vigilance against the indiscriminate trapping of adult birds, are identified as key conditions to stabilize and recover mainland Grey Parrot populations and indeed large parrots generally, given their very similar ecological traits and anthropogenic circumstances.
\end{abstract}

\section{Introduction}

Parrots (Psittaciformes) are among the most imperilled bird orders, with $28 \%$ of species currently Threatened and 24\% Near Threatened (BirdLife International 2020a), with large species being three times more likely at risk than small ones (Collar 1998). Most parrot species are threatened by a combination of habitat loss or degradation and excessive trade (Snyder et al. 2000, BirdLife International 2020a). Grey Parrot Psittacus erithacus has a huge range in West and Central Africa, but populations have been subjected to intense anthropogenic pressures (BirdLife International 2020b). Over the last 30 years the species' habitat has been disappearing at increasing speed (Achard et al. 2002, Duveiller et al. 2008), and tens of thousands of individuals have been harvested from the wild to satisfy a multi-million dollar international pet trade (Martin 2017, UNEP-CITES 2017). The species' global conservation status rapidly deteriorated from Near Threatened through Vulnerable to Endangered in just five years (BirdLife International 2020b), resulting in a near-unanimous acceptance of calls for a ban on its international trade in 2016 (CITES 2017).

Population trends in the Grey Parrot have not been geographically uniform: its status ranges from reasonably common in parts of Cameroon (Fotso 1998, Marsden et al. 2016) to declining in DRC (Hart et al. 2016) and Côte d'Ivoire (Marsden et al. 2016), to almost extinct in Ghana (Annorbah et al. 2016) and Nigeria (Martin et al. 2014, Olmos \& Turshak 2009). However, despite a long history of commercial trade in Grey Parrots, the island of Príncipe (Democratic Republic of São Tomé and Príncipe) still hosts an abundant population (Valle et al. 2018), with a remarkably high overall mean density of $53 \pm 6$ parrots $\mathrm{km}^{-2}$ across the island (Valle et al. 2017). Although the Grey Parrots on Príncipe present some genetic complexity, with one lineage involving Psittacus erithacus and one involving Timneh Parrot P. timneh (Melo \& O'Ryan 2007), there is no evidence that their ecology is significantly different from populations of either species on the African mainland.

In this paper we seek to explore the various factors that might individually or in combination explain why the Grey Parrot population on Príncipe maintains such notable densities while other populations are dwindling. 


\section{Methods}

\section{Study area}

Príncipe $\left(139 \mathrm{~km}^{2}\right)$ lies close to the equator, $220 \mathrm{~km}$ off the coast of West Africa, in the Gulf of Guinea (Supplementary online material figure S1). It was uninhabited until 1471, after which all sufficiently accessible areas were gradually cleared and planted with sugarcane Saccharum sp., oil palm Elaeis guineensis, cocoa Theobroma cacao, coffee Coffea sp. and coconut Cocos nucifera. Many of these areas have now reverted to secondary forest, while, from our own calculations using GIS, $25 \%$ of the island (mostly in the southern half) retains almost untouched lowland rainforest (Figueiredo et al. 2011, Jones \& Tye 2006). Príncipe has a depauperate land fauna, with only 31 breeding bird species (Jones \& Tye 2006), 11 reptiles and three amphibians (Ceríaco et al. 2018), and five native mammal species (four bats and one shrew), albeit with high levels of endemism (Jones 1994).

\section{Review}

We reviewed all available evidence concerning those factors which are known to be key to the viability of parrot populations. These include natural ecological aspects as well as indirect and direct anthropogenic pressure. Availability of suitable nesting cavities is a key factor for most parrot species as it imposes a direct limitation on their yearly breeding output (Beissinger 2001, Beissinger \& Bucher 1992, Munn 1992). Natural nest predation is another important aspect as it can be accountable for more than $50 \%$ of nest failures in some populations (Berkunsky et al. 2016, Renton \& Salinas-Melgoza 2004). Changes in food resource availability and accessibility have also been linked to the decline of wild parrots (Berg et al. 2007, Saunders 1990, Wunderle 1999). Furthermore, as most Psittacidae rely on tropical and subtropical forests, habitat loss has been highlighted as one of the main threats at both local and global levels, particularly when associated with agricultural expansion (Koenig 2008, Vergara-Tabares et al. 2020). Finally, harvest for the local and international pet trade is thought to be responsible for the decline of many parrot species due to their peculiar life history traits, i.e. small clutch size, long period of parental care, slow sexual maturation and long lifespan (González 2003, Martin et al. 2014, 2018, Valle et al. 2018). We then examined how the same conditions may differ in mainland Africa and how this may influence the health of populations of this and other large parrot species.

\section{Results}

\section{Nesting requirements, densities and productivity}

Grey Parrots are obligate secondary tree-cavity nesters (Benson et al. 1988), which makes them particularly sensitive to the loss of suitable cavities to tree-felling or competition (Valle et al. 2017). On Príncipe, 66 of 83 (79\%) nest cavities examined were found in four relatively common and widespread tree species (Valle 2015; Supplementary online material table S1). Pairs nested in large trees (mean nest-tree height $\pm \mathrm{SD}=45.3 \pm 14.0 \mathrm{~m}$; $\mathrm{DBH}=1.22 \pm 0.49 \mathrm{~m}$ ), and all but four nests were in living healthy trees (Valle 2015). This is consistent with the species' behaviour elsewhere (Amuno et al. 2010, Dändliker 1992) and indeed with larger parrot species across the tropics (Marsden \& Jones 1997, Monterrubio-Rico et al. 2006).

Although the loss of habitat in general is a major threat to Grey Parrot populations (BirdLife International 2020b), the loss of individual large trees providing nesting substrate can be equally detrimental to their viability (Valle et al. 2017). In some cases, preferred nest trees may be of significant commercial value, e.g. Terminalia superba for timber in Ghana (Dändliker 1992) and Pentaclethra macrophylla for charcoal in Príncipe (Valle 2015). Indeed, in Ghana, the felling of individual large trees within the landscape is thought to have greatly compounded the effects of trade in the species (Annorbah et al. 2016).

Nest densities at traditional trapping sites on Príncipe averaged $72 \pm 26$ (SD) nests km$~^{-2}$ in primary forest and $17 \pm 8$ nests $\mathrm{km}^{-2}$ in secondary forest (Valle 2015). While nest densities across the island as a whole may be lower than those at selected trapping sites, they are nonetheless the highest ever recorded for any native, noncolonial, tree-nesting parrot species (Table 1). The only other estimate of nest density for Grey Parrots is $1.3 \pm 0.13$ (SD) nests $\mathrm{km}^{-2}$ in Nigeria (as in this study, minimum density was calculated from local trappers' knowledge; McGowan 2001).

On Príncipe, nests were reported by trappers to have produced $1-3$ chicks (mean $\pm \mathrm{SD}=1.9 \pm 0.7, \mathrm{n}=81$; Valle 2015). Such productivity is high but within the normal range of the species (1-4; Benson et al. 1988, Forshaw 1989).

\section{Nest competitors and nest predators}

On Príncipe, Grey Parrot is the largest hole-nesting vertebrate (Jones \& Tye 2006), freeing it from interspecific competition for cavities, a limiting factor for many bird species (Martin \& Eadie 1999, Strubbe \& Matthysen 2009). The absence of hornbills (Bucerotidae) may be particularly important, since these are the most likely nest-site competitors across the Grey Parrot's range, and because they can occur at relatively high densities, e.g. Black-casqued Hornbills Ceratogymna atrata at $8.7 \pm 0.6 \mathrm{~km}^{-2}$ and Brown-cheeked Hornbills Bycanistes cylindricus at $7.2 \pm 1$ $\mathrm{km}^{-2}$ in Cameroon (Whitney \& Smith 1998). Indeed, the only documented instance of nest competition on a Grey Parrot involved a Grey-cheeked Hornbill B. subcylindricus killing a brood in order to appropriate the cavity (Kalina 1988). Also absent from Príncipe is a suite of tree-dwelling mammals (e.g. Galagidae, Viverridae, Mustelidae), which may likewise compete for nest holes in mainland West and Central Africa.

Other than the introduced mona monkey Cercopithecus mona and black rat Rattus rattus, which may despoil unguarded nests (Jones \& Tye 2006), there are no confirmed nest predators on Príncipe (Dutton 1994). Nest predation can seriously affect productivity and density in parrots (Britt et al. 2014), and in mainland Africa the same mustelids and viverrids that compete for cavities may also be predators on hole-nesting animals, as are various arboreal primates and snakes, e.g. Patas monkey Erythrocebus patas (Hall 1965) and royal python Python regius (Luiselli \& Angelici 1998).

\section{Food resources}

Grey Parrots feed on fruits and seeds from a variety of common species, with a marked preference for oil palm fruits (Benson et al. 1988, Brosset \& Erard 1986), and 17 known 'food tree species' (Chapman et al. 1993, Dändliker 1992, Juste 1996, Tamungang \& Ajayi 2003). This diet allows the species to occupy a range of disturbed habitats, including secondary forest (Dändliker 1992), shade plantations (Valle et al. 2017) and even urban environments (Irumba et al. 2016, Martin et al. 2014). Príncipe's landscapes are rich in Grey Parrot food, with a mean $4 \pm 2$ (SD) of the 17 known food tree species per sampling plot 
Table 1. Nest densities (nests $\mathrm{km}^{-2}$ ) for parrot species in previously published studies and the current study, in ascending order. NB. Caution needs to be taken in comparing the figures as methods used to calculate densities vary.

\begin{tabular}{|c|c|c|c|c|c|}
\hline Species & Location & Density \pm SD (range) & Habitat type & Reference & Methods/notes \\
\hline $\begin{array}{l}\text { Hyacinth Macaw } \\
\text { Anodorhynchus hyacinthinus }\end{array}$ & $\begin{array}{l}\text { Pantanal, } \\
\text { Brazil }\end{array}$ & 0.045 & $\begin{array}{l}\text { Savanna, forest } \\
\text { patches, flood } \\
\text { plains }\end{array}$ & $\begin{array}{l}\text { Pinho \& } \\
\text { Nogueira (2003) }\end{array}$ & Methods not described \\
\hline $\begin{array}{l}\text { Blue-fronted Amazon } \\
\text { Amazona aestiva }\end{array}$ & $\begin{array}{l}\text { Pantanal, } \\
\text { Brazil }\end{array}$ & $\begin{array}{l}0.26 \pm 0.3 \\
(0.03-0.5)\end{array}$ & $\begin{array}{l}\text { Savanna, forest } \\
\text { patches flood } \\
\text { plains }\end{array}$ & $\begin{array}{l}\text { Fernandes Seixas } \\
\text { \& Mourão (2002) }\end{array}$ & $\begin{array}{l}\text { Active nests located by following } \\
\text { individuals to nests and information } \\
\text { from trappers }\end{array}$ \\
\hline $\begin{array}{l}\text { Grey Parrot } \\
\text { Psittacus erithacus }\end{array}$ & Nigeria & $\begin{array}{l}1.3 \pm 0.13 \\
(0.5-2.1)\end{array}$ & Various & McGowan (2001) & $\begin{array}{l}\text { Calculated from local trappers' } \\
\text { knowledge. Minimum nest density }\end{array}$ \\
\hline $\begin{array}{l}\text { Scarlet Macaw } \\
\text { Ara macao } \\
\text { Blue-and-yellow Macaw } \\
\text { Ara ararauna } \\
\text { Green-winged Macaw } \\
\text { Ara chloroptera }\end{array}$ & $\begin{array}{l}\text { Manu NP, } \\
\text { Peru }\end{array}$ & 6.1 & Rain forest & $\begin{array}{l}\text { Nycander et al. } \\
\text { (1995) }\end{array}$ & $\begin{array}{l}\text { Nest/cavity search. Density calculated } \\
\text { across all species through extrapola- } \\
\text { tion }\end{array}$ \\
\hline $\begin{array}{l}\text { Grey Parrot } \\
\text { Psittacus erithacus }\end{array}$ & Príncipe & $\begin{array}{l}41.5 \pm 33.9 \\
(8.8-101.0)\end{array}$ & $\begin{array}{l}\text { Lowland rain } \\
\text { forest }\end{array}$ & This study & $\begin{array}{l}\text { Calculated from local trappers' } \\
\text { knowledge. Minimum nest density }\end{array}$ \\
\hline
\end{tabular}

( $n=103), 99 \%$ containing at least one such species and $89 \%$ containing oil palms (Valle et al. 2017). As with other parrot species (Marsden \& Pilgrim 2003), such adaptability contributes to the species' resilience to some anthropogenic land-use changes. Thus, habitat loss is more likely to affect populations of Grey Parrot, and other large psittacids, in terms of lower nestsite availability than lower food availability (Beissinger \& Bucher 1992, Munn 1992, Newton 1994).

\section{Trade volume, patterns and limitations}

With over 1.6 million individuals legally exported from range states between 1975 and 2014, Grey Parrot was then the most traded wild bird species in the world (Martin 2017, UNEPCITES 2017). Despite this, the supply of birds remained strong until growing concerns over the state of wild populations led to a ban on its trade in 2016 (CITES 2017). Príncipe has a history of heavy trade in Grey Parrots, with a reported average of 600 chicks - approximating to four individuals per $\mathrm{km}^{2}$ of its land area - exported annually in the 1990s (Juste 1996). Nonetheless, the island appears always to have hosted reasonably high densities (Jones \& Tye 2006, Melo \& O'Ryan 2007), which have been slowly growing since the regional ban on all trade was put in place in 2005 (Valle 2015, Valle et al. 2018). We suggest two reasons behind this resilience to trapping pressure.

First, different capture methods have markedly different impacts on Grey Parrot populations, with the harvest of adult birds being far more detrimental than that of nestlings only (Valle et al. 2018). Trapping on Príncipe has predominantly targeted chicks from nests in traditional harvest locations, with only occasional trapping at feeding sites (Melo 1998). By contrast, trapping in mainland Africa commonly involves the indiscriminate mass capture of individuals from aggregation sites (e.g. in Cameroon; Ngenyi 2002, 2003) or the capture of nest-attending adults along with destruction of the nest and/or felling of the nest tree (e.g. in Ghana; Dändliker 1992).

Second, at least $45 \%$ of Príncipe is covered by practically inaccessible primary and secondary lowland forest (Jones \& Tye 2006). This has provided parrots with an abundance of large trees suitable for nesting, a high proportion of which remain beyond the reach of poachers and other forms of disturbance due to their remoteness and the ruggedness of the terrain. This is consistent with what has been found in the congeneric Timneh Parrot, where site remoteness is linked to healthier local populations (Lopes et al. 2019). Given these conditions, together with the absence of nest competitors and predators discussed above, it is likely that, on Príncipe, many pairs of Grey Parrots, which are annual breeders (Benson et al. 1988), fledge offspring successfully every year. Moreover, the peculiar configuration of the island's landscape might be particularly favourable for Grey Parrots, as it offers areas with significant feeding opportunities (extensive plantations and secondary forest, both rich in food tree species) as well as much rugged forest suitable for breeding, allowing for daily and seasonal movements between the two (Valle 2015, Valle et al. 2017).

\section{Discussion}

While mainland African populations of Grey Parrot, and indeed most other large parrots worldwide, have been steadily declining (BirdLife International 2020a), over the years Príncipe's population has remained relatively large and seemingly growing (Valle et al. 2018). Príncipe's high population densities of parrots may be partly attributed to an island 'density compensation' effect (MacArthur et al. 1972, Wright 1980). Mainland populations also have to contend with a number of potential predators (including human) and competitors which are absent from the island (Kalina 1988). Nevertheless, some important lessons can be drawn from this case study to inform the conservation of the species elsewhere in its range. Of the four constraints potentially operating on Grey Parrot populations across Africa and which may contribute to the success of the species on Príncipe, we discount one, food resources, as improbable, but we regard the other three as significant. Although the availability of food is an unlikely constraint for Grey Parrots on Príncipe, and possibly in other lush habitats on the mainland, it should not be underestimated as it has been shown to influence local abundance (Marsden \& Pilgrim 2003) and limit population viability in other large parrot species (Saunders 1990, Berg et al. 2007).

Consequently, we recommend the following management interventions for mainland populations of Grey Parrots and other large psittacines, particularly those with very specific nesting 
requirements such as Thick-billed Parrot Rhynchopsitta pachyrhyncha (Monterrubio et al. 2002) and Yellow-eared Parrot Ognorhynchus icterotis (Krabbe 2000).

1. Efforts are needed to ensure that a proportion of Grey Parrot nests are successful each year, thereby promoting recruitment into the wild population. Protection of nests, mainly from poachers but also, in some situations, from competitors or predators (e.g. by installation of predator guard devices), is crucial.

2. The preservation of individual large trees, especially those known to hold nest holes, is vital, which may require adjustments to forestry policy and negotiations with logging stakeholders.

3. As authorities enforce the international ban on trade, they should prioritize interventions against the indiscriminate trapping of adult birds away from nests. For example, since the eyes of adult Grey Parrots are pale while those of juveniles are dark (Dändliker 1992), the trapping method employed could be deduced by recording eye colour of birds in confiscated shipments, i.e. those with $>20 \%$ of birds with pale eyes are likely to derive from indiscriminate trapping (Valle et al. 2018).

Conservation action for any species is best informed by extensive research into that species in the particular area of concern. However, the logistic and economic constraints of collecting ecological data in the tropics on large parrots indicate the need for a critical synthesis of available evidence, even from just one species, in order to provide information with a high probability of relevance to other species. Such extrapolation should nevertheless be weighed against the possibility of collecting better evidence, and allow for the assessment of the effects of any conservation intervention put in place based on surrogate species.

Acknowledgements. Parrots International generously funded our research in 2012-14. Eng. Arlindo Carvalho (former National General Director of the Environment), Eng. Nestor Umbelina (Regional Secretary to the Infrastructures and the Environment) and Daniel Ramos (former Director of the Parque Natural d'Ôbo do Príncipe) endorsed and facilitated the project. Here Be Dragons investment group kindly provided logistical support during fieldwork. Sátiro and Lynsey Crellin gave crucial assistance with data collection. The virtual library shared by the IOU Working Group on Psittaciformes was an invaluable source of both peer-reviewed and grey literature. The data that support the findings of this study are available from the corresponding author upon reasonable request. Four referees kindly provided sound advice for the improvement of the manuscript.

Supplementary material. To view supplementary material for this article, please visit https://doi.org/10.1017/S0266467421000031

\section{References}

Achard F, Eva HD, Stibig HJ, Mayaux P, Gallego J, Richards T and Malingreau JP (2002) Determination of deforestation rates of the world's humid tropical forests. Science 297, 999-1002.

Amuno JB, Massa R and Okethowengo G (2010) Some observations on nesting African Grey parrots, Psittacus erithacus, in Uganda. Rivista Italiana di Ornitologia 80, 57-59.

Annorbah NND, Collar NJ and Marsden SJ (2016) Trade and habitat change virtually eliminate the Grey parrot Psittacus erithacus from Ghana. Ibis 158, 82-91.

Beissinger SR. (2001) Trade of live wild birds: potentials, principles, and practices of sustainable use. In Reynolds J, Mace GM, Redford KH and Robinson JG (eds), Conservation of Exploited Species. Cambridge: Cambridge University Press, pp. 182-202.
Beissinger SR and Bucher EH (1992) Sustainable harvesting of parrots for conservation. In Beissinger SR and Snyder NFR (eds), New World Parrots in Crisis: Solutions from Conservation Biology. Washington, DC: Smithsonian Institution Press, pp. 73-115.

Benson CW, Benson FM, Stuart SN and Fry CH (1988) Parrots, parakeets and lovebirds. In Fry $\mathrm{CH}$, Keith $\mathrm{S}$ and Urban EK (eds), The Birds of Africa. London: Academic Press, pp. 1-25.

Berg KS, Socola J and Angel RR (2007) Great Green Macaws and the annual cycle of their food plants in Ecuador. Journal of Field Ornithology 78, 1-10.

Berkunsky I, Segura LN, Aramburú RM, Ruggera RA, Svagelj WS and Reboreda JC (2016) Nest survival and predation in Blue-fronted Parrots Amazona aestiva: effects of nesting behaviour and cavity characteristics. Ardea 104, 143-151.

BirdLife International (2020a) IUCN Red List for birds. Available at http:// www.birdlife.org.

BirdLife International (2020b) Species factsheet: Psittacus erithacus. Available at http://datazone.birdlife.org/species/factsheet/22724813.

Britt CR, García Anleu R and Desmond MJ (2014) Nest survival of a longlived psittacid: Scarlet Macaws (Ara macao cyanoptera) in the Maya Biosphere Reserve of Guatemala and Chiquibul Forest of Belize. The Condor 116, 265-276.

Brosset A and Erard C (1986) Les oiseaux des régions forestières du nord-est du Gabon. Volume 1. Écologie et comportement des espèces. Revue d'Écologie (La Terre et la Vie) 1, 1-297.

Ceríaco LMP, Marques MP and Bauer AM (2018) Miscellanea Herpetologica Sanctithomae, with a provisional checklist of the terrestrial herpetofauna of São Tomé, Príncipe and Annobon Islands. Zootaxa 4387, 91-108.

Chapman C, Chapman L and Wrangham R (1993) Observations on the feeding biology and population ecology of the Grey Parrot Psittacus erithacus. Scopus 16, 89-93.

CITES (2017) Notification to the parties No. 2017/010 - Reservations on Appendices I and II.

Collar NJ (1998) Information and ignorance concerning the world's parrots: an index for twenty-first century research and conservation. Papageienkunde 2, 201-235.

Dändliker G (1992) The Grey Parrot in Ghana: a population survey, a contribution to the biology of the species, a study of its commercial exploitation and management recommendations. A report on CITES Project S-30.

Dutton J (1994) Introduced mammals in São Tomé and Príncipe: possible threats to biodiversity. Biodiversity and Conservation 3, 927-938.

Duveiller G, Defourny P, Desclée B and Mayaux P (2008) Deforestation in Central Africa: estimates at regional, national and landscape levels by advanced processing of systematically-distributed Landsat extracts. Remote Sensing of Environment 112, 1969-1981.

Fernandes Seixas GH and Mourão G de M (2002) Nesting success and hatching survival of the Blue-fronted Amazon (Amazona aestiva) in the Pantanal of Mato Grosso do Sul, Brazil. Journal of Field Ornithology 73, 399-409.

Figueiredo E, Paiva J, Stévart T, Oliveira F and Smith GF (2011) Annotated catalogue of the flowering plants of São Tomé and Príncipe. Bothalia 112, 1969-1981.

Forshaw JM (1989) Parrots of the World. London: Blandford Press.

Fotso R (1998) Survey status of the distribution and utilization of the grey parrot (Psittacus erithacus) in Cameroon. Geneva: CITES Secretariat.

González JA (2003) Harvesting, local trade, and conservation of parrots in the northeastern Peruvian Amazon. Biological Conservation 114, 437-446.

Hall KRL (1965) Behaviour and ecology of the wild Patas monkey, Erythrocebus patas, in Uganda. Journal of Zoology 148, 15-87.

Hart J, Hart T, Salumu L, Bernard A, Abani R and Martin R (2016) Increasing exploitation of Grey parrots in eastern DRC drives population declines. Oryx 50, 16.

Irumba I-O, Pomeroy D and Perrin M (2016) Grey parrots Psittacus erithacus in Kampala, Uganda - are they becoming suburbanised? Ostrich 87, 193-195.

Jones PJ (1994) Biodiversity in the Gulf of Guinea: an overview. Biodiversity and Conservation 3, 772-784.

Jones P and Tye A (2006) The Birds of São Tomé \& Príncipe, with Annobón, Islands of the Gulf of Guinea: An Annotated Checklist. BOU Checklist Series no. 22. Oxford: British Ornithologists' Union. 
Juste JB (1996) Trade in the gray parrot Psittacus erithacus on the Island of Principe (São Tomé and Príncipe, Central Africa): initial assessment of the activity and its impact. Biological Conservation 76, 101-104.

Kalina J (1988) Ecology and behavior of the black-and-white casqued hornbill (Bycanistes subcylindricus subquadratus) in Kibale Forest, Uganda. Michigan State University.

Koenig SE (2008) Black-billed parrot (Amazona agilis) population viability assessment (PVA): a science-based prediction for policy makers. Ornitologia Neotropical 19, 135-149.

Krabbe N (2000) Overview of conservation priorities for parrots in the Andean region with special consideration for Yellow-eared parrot. International Zoo Yearbook 37, 283-288.

Lopes DC, Catry P, Henriques M, Martin RO, Monteiro H, Cardoso P, Tchantchalam Q, Pires AJ and Regalla A (2019) Combining local knowledge and field surveys to determine status and threats to Timneh Parrots Psittacus timneh in Guinea-Bissau. Bird Conservation International 29, 400-412.

Luiselli L and Angelici FM (1998) Sexual size dimorphism and natural history traits are correlated with intersexual dietary divergence in royal pythons (Python regius) from the rainforests of southeastern Nigeria. Italian Journal of Zoology 65, 183-185.

MacArthur RH, Diamond JM and Karr JR (1972) Density compensation in island faunas. Ecology 53, 330-342.

Marsden SJ and Jones MJ (1997) The nesting requirements of the parrots and hornbill of Sumba, Indonesia. Biological Conservation 82, 279-287.

Marsden SJ and Pilgrim JD (2003) Factors influencing the abundance of parrots and hornbills in pristine and disturbed forests on New Britain, PNG. Ibis 145, 45-53.

Marsden SJ, Loqueh E, Takuo JM, Hart JA, Abani R, Ahon DB, Annorbah N, Johnson R and Valle S (2016) Using encounter rates as surrogates for density estimates makes monitoring of heavily-traded grey parrots achievable across Africa. Oryx 50, 617-625.

Martin K and Eadie JM (1999) Nest webs: a community-wide approach to the management and conservation of cavity-nesting forest birds. Forest Ecology and Management 115, 243-257.

Martin RO (2017) Grey areas: temporal and geographical dynamics of international trade of Grey and Timneh Parrots (Psittacus erithacus and P. timneh) under CITES. Emu-Austral Ornithology 118, 113-125.

Martin RO, Perrin MR, Boyes RS, Abebe YD, Annorbah ND, Asamoah A, Bizimana D, Bobo KS, Bunbury N, Brouwer J, Diop MS, Ewnetu M, Fotso RC, Garteh J, Hall P, Holbech LH, Madindou IR, Maisels F, Mokoko J, Mulwa R, Reuleaux A, Symes C, Tamungang S, Taylor S, Valle S, Waltert $\mathbf{M}$ and Wondafrash $\mathbf{M}$ (2014) Research and conservation of the larger parrots of Africa and Madagascar: a review of knowledge gaps and opportunities. Ostrich 85, 205-233.

Martin RO, Senni C and D'Cruze NC (2018) Trade in wild-sourced African grey parrots: insights via social media. Global Ecology and Conservation 15, e00429.

McGowan P (2001) Status, management and conservation of the African Grey Parrot, Psittacus erithacus in Nigeria. Geneva: CITES.

Melo M (1998) Differentiation between Príncipe Island and mainland populations of the African Grey parrot Psittacus erithacus: genetic and behavioural evidence and implications for conservation. Cape Town: Percy FitzPatrick Institute of African Ornithology, University of Cape Town.

Melo M and O'Ryan C (2007) Genetic differentiation between Príncipe Island and mainland populations of the grey parrot (Psittacus erithacus), and implications for conservation. Molecular Ecology 16, 1673-1685.

Monterrubio-Rico TC, Cruz-Nieto J, Enkerlin-Hoeflich E, Venagas-Holguin D, Tellez-Garcia L and Marin-Togo C (2006) Gregarious nesting behavior of Thick-billed parrots (Rhynchopsitta pachyrhyncha) in aspen stands. The Wilson Journal of Ornithology 118, 237-343.
Monterrubio T, Enkerlin-Hoeflich E and Hamilton RB (2002) Productivity and nesting success of Thick-billed parrots. The Condor 104, 788-794.

Munn CA (1992) Macaw biology and ecotourism, or 'When a bird in the bush is worth two in the hand'. In Beissinger SR and Snyder NFR (eds), New World Parrots in Crisis: Solutions from Conservation Biology. Washington, DC: Smithsonian Institution, pp. 47-72.

Newton I (1994) The role of nest sites in limiting the numbers of hole-nesting birds: a review. Biological Conservation 70, 265-276.

Ngenyi A. (2002) African Grey parrot trade in Cameroon. PsittaScene 50, 2-3.

Ngenyi A (2003) The African Grey parrot status and commercial exploitation in Cameroon. WWF, Jengi SE project.

Nycander E, Blanco D, Holle K, Del Campo A, Munn C, Moscoso J, Ricalde D, Abramson J, Speer B and Thomsen J (1995) Manu and Tambopata: nesting success and techniques for increasing reproduction in wild macaws in southeastern Peru. In Abramson J, Speer BL and Thomsen JB (eds), The Large Macaws: Their Care, Breeding and Conservation. Fort Bragg: Raintree, pp. 423-443.

Olmos F and Turshak LG (2009) A survey of birds in Omo Forest Reserve, south-western Nigeria. Bulletin of the African Bird Club 16, 184-196.

Pinho JB and Nogueira FMB (2003) Hyacinth Macaw (Anodorhynchus hyacinthinus) reproduction in the Northern Pantanal, Mato Grosso, Brazil. Ornitologia Neotropical 14, 29-38.

Renton K and Salinas-Melgoza A (2004) Climatic variability, nest predation, and reproductive output of Lilac-crowned parrots (Amazona finschi) in tropical dry forest of western Mexico. The Auk 121, 1214-1225.

Saunders DA (1990) Problems of survival in an extensively cultivated landscape: the case of Carnaby's cockatoo Calyptorhynchus funereus latirostris. Biological Conservation 54, 277-290.

Snyder NFR, McGowan P, Gilardi JD and Grajal A (2000) Parrots: Status Survey and Conservation Action Plan 2000-2004. Gland and Cambridge: IUCN.

Strubbe D and Matthysen E (2009) Experimental evidence for nest-site competition between invasive ring-necked parakeets (Psittacula krameri) and native nuthatches (Sitta europaea). Biological Conservation 142, 1588-1594.

Tamungang SA and Ajayi SS (2003) Diversity of food of the Grey parrot Psittacus erithacus in Korup National Park, Cameroon. Bulletin of the African Bird Club 10, 33-36.

UNEP-CITES (2017) CITES trade database. Available at https://trade. cites.org/.

Valle S (2015) Population viability and conservation of Grey Parrots Psittacus erithacus on the island of Principe, Gulf of Guinea. PhD Thesis Manchester Metropolitan University, UK.

Valle S, Collar NJ, Harris WE and Marsden SJ (2017) Spatial and seasonal variation in abundance within an insular grey parrot population. African Journal of Ecology 55, 433-442.

Valle S, Collar NJ, Harris WE and Marsden SJ (2018) Trapping method and quota observance are pivotal to population stability in a harvested parrot. Biological Conservation 217, 428-436.

Vergara-Tabares DL, Cordier JM, Landi MA, Olah G and Nori J (2020) Global trends of habitat destruction and consequences for parrot conservation. Global Change Biology 26, 4251-4262.

Whitney KD and Smith TB (1998) Habitat use and resource tracking by African Ceratogymna hornbills: implications for seed dispersal and forest conservation. Animal Conservation 1, 107-117.

Wright SJ (1980) Density compensation in island avifaunas. Oecologia 45, 385-389.

Wunderle JM (1999) Pre- and post-hurricane fruit availability: implications for Puerto Rican parrots in the Luquillo Mountains. Caribbean Journal of Science 35, 249-264. 